UDK: 621.38:620.9

DOI: https://doi.org/10.24867/06BE20Mamlic

\title{
ЕЛЕКТРОМАГНЕТНА КОМПАТИБИЛНОСТ ПРЕТВАРАЧА ЕНЕРГЕТСКЕ ЕЛЕКТРОНИКЕ У ИНДУСТРИЈИ
}

\section{ELECTROMAGNETIC COMPATIBILITY OD POWER ELECTRONICS IN INDUSTRY}

Горан Мамлић, Веран Васић, Ђура Орос, Факултет техничких наука, Нови Сад

\begin{abstract}
ОбЛаст - ЕЛЕКТРОТЕХНИКА И РАЧУНАРСТВО
Кратак садржај - У овом раду приказани су неки аспекти везани за електромагнетпу компатибилност претварача енергетске електронике у индустрији. Стављен је аспекат на утицај електромагнетних сметњи, рад фреквентних претварача, генерисање електромагнетних сметни од стране фреквентних претварача, примену електромагнетске компатибилности у пракси.
\end{abstract}

Кључне речи: Електромагнетска компатибилност, фреквентни претварачи, електромагнетске сметње.

\begin{abstract}
This paper presents some aspects related to the electromagnetic compatibility of power electronics converters in industry. The aspect was put on the influence of electromagnetic interference, operation of frequency converters, generation of electromagnetic interference by frequency converters, application of electromagnetic compatibility in practice.
\end{abstract}

Keywords: Electromagnetic compatibility, frequency converters, electromagnetic interference.

\section{1. УВОД}

Са сталним развојем технологије и повећањем индустријске производње последњих година долази до тога да је потребна све већа ефикасност и сигурност свих структура које учествују у производњи.

Раст електро индустрије довео је до тога да долази до целокупног искоришћења електромагнетног спектра за обављање многих задатака повезаних са различитим гранама индустрије.

Са повећањем сметњи како у индустрији тако и у стамбеном сектору намеће се потреба да се електромагнетне сметње на неки начин елиминишу. Како је немогуће елиминисати у потпуности све врсте сметњи долази до развоја стандарда који описују технике за њихово смањење.

Уводи се појам електромагнетне компатибилности уређаја. Данас приликом производње електронских уређаја мора се водити рачуна да дати уређај у окружењу неће допринети повећању електромагнетних сметњи, као и да окружење не утиче на електрични уређај.

\section{НАПОМЕНА:}

Овај рад проистекао је из мастер рада чији ментор је био др Веран Васић, ред. проф.

\section{2. ЕЛЕКТРОМАГНЕТНА КОМПАТИБИЛНОСТ}

\subsection{Oпште}

Електрична, електромеханичка и електронска опрема мора бити у складу са спецификацијама које имају за циљ да осигурају електромагнетну компатибилност која је према IEC (енг. International Electrical Commission) објави под називом IEC 60050 познатој и као „Electropedia - IEV“ дефинисана као:

- „Способност уређаја, опреме или система да задовољавајуће функционише у свом електромагнетном окружењу без увођења неподношљивих електромагнетних сметњи било ком уређају у том окружењу.“

Према IEC 60050 дефиниција електромагнетне сметње је:

- „Сваки електромагнетни феномен који може да погорша карактеристике рада електричног уређаја, опреме или целокупног система, или негативно да утиче на животну околину или инертну материју. Електромагнетна сметња може бити електромагнетна бука, нежељени сигнал или промена карактеристика саме средине.“

У суштини електромагнетна сметња (енг. EMI Electromagnetic interference) која се у радио фреквенцијском опсегу назива и радио - фреквентна интерференција (енг. RFI - Radio frequency interference) се састоји од било ког нежељеног, лажног, и / или зраченог сигнала електричног порекла које може изазвати неприхватљиву деградацију карактеристика система или опреме. Ефекти које електромагнетна сметња може да изазове могу да се крећу од мање неугодности до катастрофалних последица. Електромагнетне сметње обухватају распон фреквенције од $0 \mathrm{~Hz}$ до $400 \mathrm{GHz}$.

\section{2. Извори електромагнетских сметњи}

Како се густина електромагнетног окружења наставља повећавати због све веће употребе различитих електричних и електронских уређаја, забринутост о ефектима из извора који производе електромагнетне сметње такође се повећава. Електромагнетна компатибилност увек има два комплементарна аспекта.

Свака ситуација некомпатибилности мора имати извор електромагнетних сметњи и пријемник (опрема 
или уређај - потрошач) који је подложан овим сметњама. Ако било ко од њих није присутан, нема проблема везаних за електромагнетну компатибилност. Иста опрема може бити извор у једној ситуацији и пријемник у другој. Извори електромагнетних сметњи могу да се класификују као људски створени или природни. Из основа електротехнике знамо да „протицање“ електричне струје кроз електричне проводнике доводи до појаве електромагнетног поља око датог проводника. Створено електромагнетно поље може да изазове сметње уређајима који се нађу у његовој околини. На основу овога може се закључити да сваки електрични или електронски уређај који преноси, дистрибуира, обрађује или на други начин користи било који облик електричне енергије може бити потенцијални извор електромагнетних сметњи ако било који аспект његовог рада генерише електромагнетне сигнале који могу проузроковати деградацију перформанси било које опреме или система који дели исто оружење.

Како су електромагнетне сметње директно пропорционалне фреквенцији (простиру се као таласи) у електромагнетној компатибилности користи се фреквентни домен за описивање дејства сметњи и њихове компензације. У оваквом начину представљања, периодични сигнали се представљају као сума хармоника. Фреквенција и таласна дужина електромагнетне сметње (таласа) остварују везу према следећој једначини (2.2.1):

$$
c=\lambda \cdot f[\mathrm{~m} / \mathrm{s}]
$$

где су:

- $c$ - брзина светлости (ширења таласа), $c=3 \cdot 10^{8}[\mathrm{~m} / \mathrm{s}]$,

- $f$ - фреквенција таласа $[1 / \mathrm{s}],[\mathrm{Hz}]$,

- $\lambda$ - таласна дужина [m].

У фреквентном домену најчешће се користи следећа једначина за описивање промене величине слабљења:

$$
p=10 \cdot \log \frac{P_{1}}{P_{2}}[d B]
$$

где су:

- $\mathrm{p}$ - слабљење изражено у децибелима у фреквентном домену,

- $\mathrm{P}_{1}$ - амплитуда величине на извору (уређају),

- $\mathrm{P}_{2}$ - амплитуда величине у датој тачки.

\subsection{1. Преношење сметњи путем каблова,} сигналних каблова, електроенергетских водова

Најједноставнији начин преноса електромагнетних сметњи је путем директне везе између извора електромагнетне сметње и пријемника. Најбољи пример који описује наведено, је веза преко електричне мреже којом се напајају потрошачи. Електромагнетне сметње присутне на излазима мрежног напајања путем електричних водова, електроенергетских каблова преносе се до мрежних улаза напајања потрошача (пријемника). Сама мрежа снабдевања електричном енергијом обично се сматра пасивним учесником приликом преноса електро- магнетних сметњи. Поремећаји дуж водова, каблова, могу да се простиру путем њих на следећи начин:

- диференцијални начин спрезања (енг. differentnial mode coupling),

- $\quad$ спрезање преко заједничке импедансе (енг. common mode coupling).

Диференцијални начин спрезања тј. преноса електромагнетних сметњи огледа се у томе да се сметње простиру између фазних проводника. Спрезање преко заједничке импедансе тј. пренос електромагнетних сметњи представља пренос путем свих проводника у систему гледано у односу на земљу као референтни вод (заједнички вод). На слици 1 приказан је пренос електромагнетних сметњи преко заједничке импедансе.

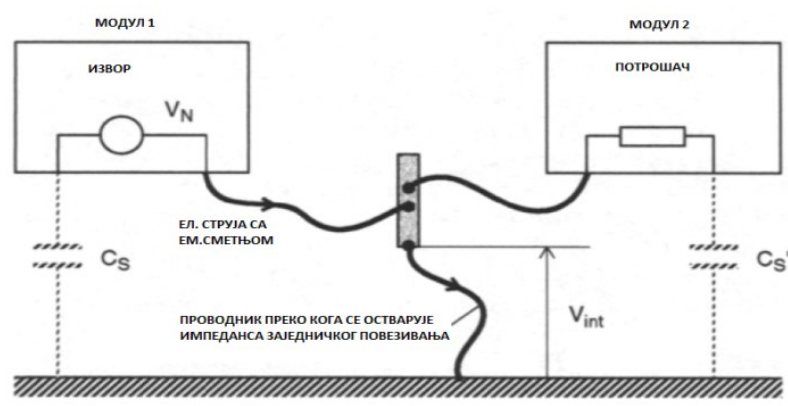

Слика 1. Пренос електромагнетних сметьи преко заједничке импедансе.[1]

\subsection{2. Преношење сметњи путем електромагнетних поља}

Електрични уређаји (потрошач, извор електромагнетне сметње) не морају бити директно спојени да би дошло до преноса сметњи између њих. Као што је већ наведено, електрична струја која „протиче“ кроз проводник, око тог проводника ствара магнетно поље, а ако постоји напон између проводника ствара се и електрично поље.

Свако од ових поља способно је да индукује напон у другом струјном кругу који се налази у домену тих поља. Преношење сметњи (поремећаја) можемо разликовати на два начина:

- $\quad$ индуктивно спрезање - магнетно (енг. inductive coupling),

- $\quad$ капацитивно спрезање - електрично (енг. capacitive coupling).

Према закону електромагнетне индукције - Фарадејев закон (енг. Michael Faraday) ако се у магнетном пољу нађе проводник који се креће, или се магнетно поље креће око датог проводника на крајевима тог проводника долази до појаве електричног напона тј. индукује се електрични напон на крајевима датог проводника. Ако је струјни круг затворен успоставиће се и електрична струја кроз поменути проводник. Једначина која описује наведену појаву дефинисана је на следећи начин:

$$
V_{N}=-M \cdot \frac{d i}{d t}[V]
$$

где су: 
- $\mathrm{V}_{\mathrm{N}}$ - индуковани електрични напон на крајевима посматраног проводника [V],

- $\mathrm{M}$ - међусобна индуктивност као последица електромагнетног спрезања [H],

- $\frac{d i}{d t}-$ промена електричне струје у времену која ствара магнетно поље.

Индуковани напон на крајевима проводника суперпонира се на већ постојеће напоне у струјном кругу и на тај начин изазива сметње (поремећаје), овај напон не утиче на импедансу потрошача. Међусобна индуктивност одређена је размаком између проводника, дужином датих проводника, њиховом геометријом, као и присуством било ког другог страног поља између њих. Најчешћа ситуација у којој je магнетна спрега значајна је када се неколико различитих струјних кругова преноси заједно у једном кабелу. Допуна магнетној спрези укључује капацитивност која се може појавити између електричних уређаја, електричних уређаја и референтне тачке тј. земље и посредно електричног поља које се појављује између њих. Када се између два електрична уређаја (проводника) појави разлика напона, ствара се електрично поље. Ово поље индукује напон на пријемнику који је сразмеран са:

$$
V_{N}=-C_{C} \cdot Z_{N} \cdot \frac{d V_{S}}{d t}[V]
$$

где су:

- $\mathrm{V}_{\mathrm{N}}$ - индуковани електрични напон у колу пријемника (на „крајевима““ потрошача) [V],

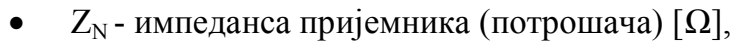

- $\mathrm{C}_{\mathrm{C}}$ - капацитивност између електричних уређаја $[\mathrm{F}]$,

- $\mathrm{V}_{\mathrm{S}}$ - електрични напон извора електромагнетне сметње (поремећаја) [V],

Можемо приметити да у односу на спрезање путем магнетног поља које зависи од фреквенције извора, спрезање путем електричног поља у значајној мери зависи од импедансе потрошача, па према томе електрична кола са великом импедансом су подложна спрезању путем електричног поља, а извор и пријемник морају бити референтни једно у односу на друго.

Пренос сметњи путем индуктивне и капацитивне спреге не може се избећи, али се кућиште уређаја може пројектовати тако да оно не постане ефикасна антена или проводна средина на одређеном опсегу учестаности у средини у којој се може наћи приликом употребе.

\section{4. Закони, правилници, стандарди који дефинишу електромагнетну компатибилност}

Свака држава доноси законску регулативу која одговара њеним потребама и условима у којима се користи комерцијална и индустријска опрема. Поред наведеног први и основни захтев који се увек ставља је безбедност опреме за рад и њен утицај на човека. Законске регулативе се дефинишу тако да електрична, електронска па и свака друга опрема за рад не доводи до штетних услова за рад човека, утицаја на животну средину.
Законска регулатива Републике Србије ослања се на законе, правилнике и уредбе који се позивају на одређење хармонизоване стандарде који су у складу са Европском и Интернационалном стандардизацијом. Република Србија као потписница чланица за приступање Европској Унији у области електромагнетне компатибилности ослања се на Европску директиву о електромагнетној компатибилности под називом "Directive 2014/30/EU of the European parliament and of the council on the harmonisation of the laws of the Member States relating to electromagnetic compatibility."

Стандарди одређују методе и границе мерења или нивое испитивања за емисију и имунитет електричне опреме, електричних инсталација и система. Подела европских стандарда на различите категорије олакшава проналажење правила која се односе на одговарајућу опрему. Генерички стандарди неприметно се примењују на сву опрему. Ако је опрема у оквиру специфичних породица производа, стандарди се могу користити за проверу усаглашености опреме са локалним законима. Основи стандарди садрже информације о појавама сметњи и општим методама мерења.

\section{3. ПРЕТВАРАЧИ ЕНЕРГЕТСКЕ ЕЛЕКТРОНИКЕ У ИНДУСТРИЈИ}

Механички рад представља основу производње људског друштва. Што је већа количина механичког рада произведена по појединцу то је виши животни стандард посматране земље. Претварање механичке енергије у електричну и обрнуто у највећем броју случајева врше електромотори. Електромотори који су највише заступљени у индустрији су трофазни асинхрони мотори, а то све из разлога што су једноставне конструкције и ниске цене.

Најједноставнији, а и најчешћи начин пуштања трофазних електромотора у рад је директан старт електромотора, тј. пуштање мотора у рад директним довођењем његових намотаја под трофазни мрежни напон. Описани начин пуштања у рад има одређене недостатке који се огледају у великој полазној струји електромотора која може бити и до 8 пута већа од номиналне електричне струје датог електромотора. Како су електронске компоненте временом постале јефтине за израду долази се до решења која не изискују директно пуштање мотора у рад, за производне процесе где је то од битног значаја. Ова решења огледају се у виду електронских уређаја који служе за пуштање електромотора у рад и њихову регулацију. Два уређаја која се користе за ту сврху су:

- „софт стартер“ - служи за „меко“ пуштање електричних мотора у рад,

- $\quad$ фреквентни претварач - служи за управљање и регулацију брзине електромотора.

\section{2 Фреквентни претварачи}

Фреквентни претварачи данас најчешће могу да се сретну у индустријском окружењу. Користе се да узету електричну енергију из мреже претворе у потребан облик енергије за електричне моторе. Фреквентни претварачи врше брзо укључење / 
искључење напона (имају велик однос $d u / d t$ ) у веома кратким временским интервалима. Ово се огледа у прекидању напона од $500 \div 1000 \mathrm{~V}$ за неколико $\mu$ s у зависности од снаге самог фреквентног претварача. Већина статичких фреквентних претварача који се данас користе у индустрији за регулацију и управљање брзином трофазних електричних мотора су прављени на основу два принципа:

- фреквентни претварачи без међукола,

- $\quad$ фреквентни претварачи са међуколом.

Последица употребе електронских компоненти које раде на различитим учестаностима комутације генерише електромагнетне сметње, а поред наведеног протицање електричне струје кроз фреквентни претварач ствара електромагнетно поље око њега. Ово електромагнетно поље и све сметње које генеришу електронске компоненте могу да доведу до интеракције са другим уређајима у околини фреквентног претварача, па је потребно да се поведе о електромагнетној компатибилности фреквентног претварача у датом окружењу. На слици 2 приказано је ширење сметњи код фреквентног претварача.

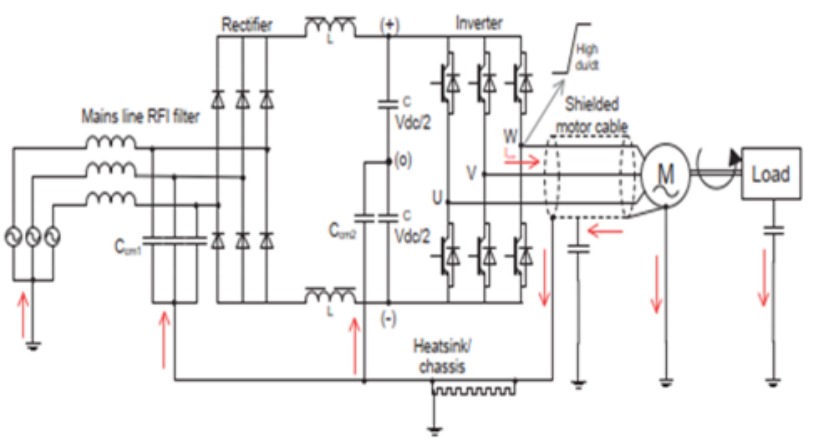

Слика 2. Ширење сметњи код фреквентног претварача [4]

Електрична струја која ствара наведену сметњу на неки начин мора да се врати у свој извор из кога је потекла. Ако се користи оклопљени кабл за напајање мотора, а оклоп кабла мотора је повезан са кућиштем мотора, а други крај оплета кабла је повезан са кућиштем фреквентног претварача, у идеалном случају, највећи део струје која изазива сметње вратиће се у једносмерно међуколо из кога је и потекла, путем спреге са заједничком импедансом земљом као референтном тачком, док ће део струје да се врати назад преко везе паразитних капацитивности. Део електричне струје сметње који се враћа назад у мрежу преко заједничке импедансе је непожељан и стога је потребна употреба филтера да би се утицај сметњи смањио да друге потрошаче у напојној мрежи.

\section{4. ЕЛЕКТРОМАГНЕТНА КОМПАТИБИЛНОСТ У ПРАКСИ}

Уземљење представља јако битан аспект за неометан рад уређаја и индустријских процеса. Уземљење је битно и са аспекта безбедности јер у случају деградације електричне изолације уређаја, не дође до могућности да метална маса било ког дела уређаја дође под напон. Безбедност има знатно већи приоритет него електромагнетна компатибилност. Под уземљењем фреквентних претварача подразумева ce повезивање металног кућишта фреквентног претварача на референтни потенцијал земље, а поред кућишта и оплета тј. ширма свих каблова који иду ка електричном мотору са којим се управља. Веома је важно да се схвати да је потребно да се оба краја оклопљеног кабела прописно повежу на референтни потенцијал земље, јер ако је само један крај повезан на потенцијал земље, може доћи до проблема са електромагнетним сметњама и ширењем сметњи према слици 2.

\section{5. ЗАКЉУЧАК}

На основу свега наведеног види се да електромагнетна компатибилност представља битан аспекат који је директно везан за неометан рад електричних уређаја а самим тим и доступност електричне енергије. Како се електрична опрема налази у разним окружењима у којима ради, јављају се разна ограничења и проблеми везани за њен рад. Да би се могао остварити неометан рад електричних уређаја у разним окружењима и доступност електричне енергије потребно је да се испуне одређени захтеви везани за квалитет производа.

Остварити оба ова циља подразумева да се разумеју појаве које се тичу извору сметњи, преноса сметњи са предајника на пријемник. Највећи део везан за електромагнетну компатибилност може се остварити већ при самом пројектовању електричних уређаја. Поред наведеног потребно је посветити и посебну пажњу карактеристикама окружења у коме he ce употребљавати електрични уређаји нпр. фреквентни претварачи.

\section{6. ЛИТЕРАТУРА}

[1] EMC for Systems and Installations, Newnes, Tim WiI Hams \& Keith Armstrong, 2000

[3] Practical Implementation - EMC in Drive Engineering, SEW EURODRIVE, 2013

[4] Facts Worth Knowing about Frequency Converters, Handbook, VLT® Frequency Converters, Danfoss, 2014

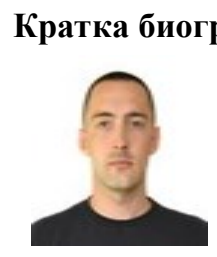

\section{Кратка биографија:}

Горан Мамлић рођен је у Новом Саду 1990. год. Дипломски рад на Факултету техничких наука из области Електротехнике и рачунарства - Енергетска електроника и електричне машине одбранио је 2017. год..

контакт: mamranlicgo@gmail.com 